\title{
Estimation of Radiation Risks Due To Ingestion of Water in Ogba/Egbema/Ndoni Local Government Area of Rivers State, Nigeria Using Risk Models
}

\author{
ONONUGBO, CP; EFERE, T
}

\author{
Radiation and Environmental Physics Research group \\ University of Port Harcourt, Port Harcourt \\ E-mail: onochinyere@yahoo.co.uk
}

\begin{abstract}
The radiation dose is the amount of energy absorbed in the body from radiation interaction. The risk of damage to tissues, cells, DNA and other vital molecules increases with every exposure to radiation. Each exposure can cause cell death, genetic mutation, cancers, leukemia, birth defects and endocrine system disorders. The aim of this study is to estimate radiation risks due to ingestion of water in Ogba/Egbema/Ndoni Local Government Area of Rivers State in Nigeria using radiation risk models. Secondary data from radiological studies on water resources of Ogba land was obtained and used to estimate excess relative risks (ERR) and excess absolute risks (EAR) for babies, children and teens of the study area. The excess relative risk (ERR) and Excess absolute risk (EAR) was calculated using a particular radiation dose, estimated age at exposure and the attained age. The result shows that relative risks decreases with increasing time after exposure. Lifetime attributable risk (LAR) was calculated from the values of excess relative risk and excess absolute risks estimated. The result of LAR shows that 102 male babies per 100,000 will likely develop cancer of the thyroid during their lifetime while 547 female babies per 100,000 will likely have cancer of the thyroid during their lifetime due to ingestion of tap water. This implies that about $84 \%$ of female and $16 \%$ of male babies will have cancer in their lifetime. This risk parameter is presented as risk per million inhabitants because the real population number has spatial and temporal variation. LAR estimated for babies, children and teenagers for different organs show that colon and lungs recorded the highest values. This study show an increasing LAR as age-at-exposure reduces. It also shows that females have generally higher risk than their male counterparts. Also well water and river water was observed to present a higher risk when compared to tap water. Therefore this study recommends the intervention of the government in providing stricter measures in regulating the use of radioactive materials in oil exploration and the oil companies operating in the region to provide enough safe drinking water for the people. (C) JASEM
\end{abstract}

https://dx.doi.org/10.4314/jasem.v21i5.8

Key words: Lifetime Attributable Risk, Excess relative risk, Radiation, dose and Exposure

The incidence of cancer in different sites of the body is on the increase as cancer has become one of the major sources of morbidity and mortality globally (Sylla and Wild, 2011). Research shows that in 2008, there were 12.7 million new incidence cases of cancer and 7.6 million deaths as a result of cancer (Ferley et. al., 2008). Reports have shown that in Nigeria alone, about 100,000 fresh cancer cases occur annually with a high mortality rate because of lack of adequate medical infrastructure (Ferley et al., 2008). Nigeria contributed about $15 \%$ to fresh cancer cases in Africa in 2008 (Sylla and Wild, 2011).

The risk factors attributed to causing the high incidence and mortality rates of cancer are; environmental pollutants such as soot, tar and crude oil, cigarette smoking, occupational and indoor exposure to asbestos, radon progeny, genetic susceptibility, low intake of fruits, vegetables and micronutrients. (Aberg and Samet, 2003; Wandwell and Massion, 2005; Alberg et al., 2005).

Polycyclic aromatic hydrocarbons are also very common in environments especially in areas where there are oil exploitation as this causes heavy presence of polycyclic aromatic hydrocarbons in the atmosphere, rivers and oceans, soil and processed foods (Adeowo and Ajayi, 2000). Radioactivity in surface water especially river water comes mainly from the radionuclide of the natural decay chains of ${ }^{238} \mathrm{U},{ }^{232} \mathrm{Th}$ and ${ }^{40} \mathrm{~K}$. The occurrence of natural radionuclide in drinking water poses a problem of health hazard, when these radionuclide are taken into the body by ingestion. The radionuclide contributing significantly to the ingestion dose via consumption of water is radium. Radium is a naturally occurring isotope found in the earth's crust, a member of the uranium ${ }^{238} \mathrm{U}$ decay series. The predominant radium isotopes in ground and surface water are ${ }^{226} \mathrm{Ra}$, an alpha emitter with half-life of 1600 years and ${ }^{228} \mathrm{Ra}$, a beta emitter with a half-life of 5.8 years ${ }^{[4]}$. Many salts of radium are soluble in water and therefore surface water may be enriched in radium and its descendant radon. ${ }^{226} \mathrm{Ra}$ is an earth alkaline element sharing the metabolic pathways of calcium in the human body. Due to their radiotoxicity especially those of ${ }^{226} \mathrm{Ra}$, a contamination hazard for humans exists even at low concentration levels (Hany ElGamal et al., 2014).

The study of the distribution of primordial radionuclide allows the understanding of the radiological implication of these elements due to gamma ray exposure of the body and irradiation of 
the lung tissue from inhalation of radon and its daughter [Uosif, et al., 2008). Radon (Rn) is a naturally occurring radioactive, odorless and colorless gas. It is very mobile in the environment. It is well known that inhalation of the short lived decay products of ${ }^{222} \mathrm{Rn}$ provides the main pathways for radiation exposure of the lungs (UNSCEAR, 2000). When radon gas is inhaled, most is exhaled before it decays but ${ }^{222} \mathrm{Rn}$ progeny may be deposited on the cells lining the airways where they can damage the DNA and potentially cause lung cancer. El-Gamal and Hosny (2008) stated that ${ }^{222} \mathrm{Rn}$ is a health hazard in both mining and non-mining environment.

Risk assessment is a method used to assess the likelihood that exposure to hazardous agents (radionuclide) will harm people or the environment and is usually conducted to estimate the probability of specific harm to an exposed individual or population. The purpose of this work is to estimate the radiation risks due to ingestion of water from different sources in Ogba/EgbemaNdoni Local Government Area of Rivers State using risk models. The result therefore, will give the probability of developing cancer at various doses of radiation absorbed by the exposed individuals. This will add data to the radiation data base of the area.
Study Area: The study area is twelve communities (Ebocha, Mgbede, Obiafu, Obrikom, Ebegoro, Omoku, Ereme, Idu-Ogba, Obagi, Ogbogene, Odugiri and Agwe) in Ogba/Egbema /Ndoni Local Government area in Nigeria. It lies within latitude $5^{0}$ $13^{1} \mathrm{~N}$ and $5^{0} 22^{1} \mathrm{~N}$ and longitude $6^{0} 33^{1} \mathrm{E}$ and $6^{0} 42^{1}$ North West of the Niger Delta region (UNDP, 2006). It is located in the central Orashi-Sombreiro plains of Rivers state, Nigeria. It is one of the major producers of crude oil that fuels Nigeria's economic development in recent decades. According to oil company records, no local government in Nigeria produces as much crude oil and gas as the Ogba/Egbema/Ndoni (ONELGA) local government.

The area has well over 900 oil wells and over thirteen active oil fields and about three multinational oil and gas companies are in the region (Abali, 2009). This makes it one of the highest oil and gas production onshore of Niger Delta. The area is saturated with network of pipelines carrying either oil or gas to the flow stations from the different oil wells (UNDP, 2006). Gas flaring and oil spillage due to rupture of pipe leakage has been the major environmental pollutant in the area (Ononugbo, 2012). The local government area has a population of about 280,000 people (Abali, 2009). Figure 1 shows the map of study area.

\section{MATERIALS AND METHOD}

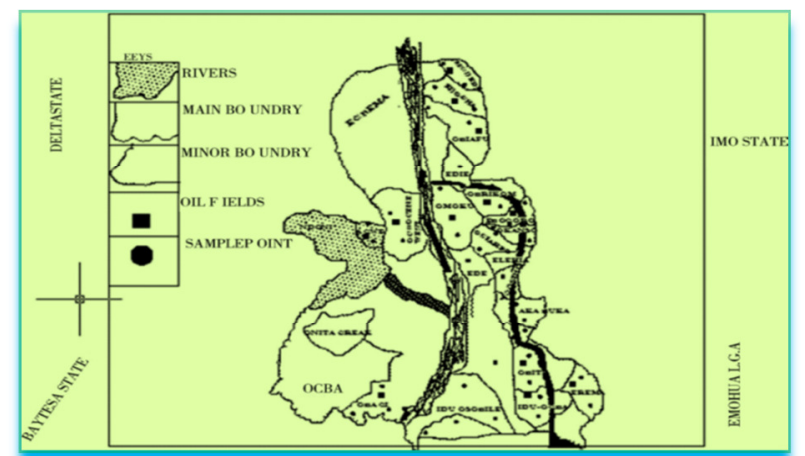

Fig. 1: Map of Ogba/Egbema/Ndoni local Govt. area of rivers state showing the study areas

Methods: Data Acquisition: The values of committed effective dose used in this study were taken from measurement of NORM in different water resources [Avwiri and Ononugbo, 2012). The specific activity concentration of ${ }^{226} \mathrm{Ra},{ }^{232} \mathrm{Th}$ and ${ }^{40} \mathrm{~K}$ (in tap, well and river water) were measured using high resolution, low background gamma spectrometer of a multichannel analyzer and coaxial high purity Germanium detector type [Avwiri and Ononugbo, 2012]. The committed effective dose calculated from the activity concentration of ${ }^{226} \mathrm{Ra},{ }^{232} \mathrm{Th}$ and ${ }^{40} \mathrm{~K}$ in tap, well and river water as adopted in this work is presented in Table 1. The mean doses were used to estimate the excess relative risk and excess absolute risk per dose of radiation. These risks due to exposure to gamma radiation are presented as risk per million inhabitants because the real population number has spatial and temporal variations.

Data Analysis: For solid cancers, there is evidence that relative risks might diminish with time after exposure. For this reason, one is led to fit a generalized relative risk model in which the cancer 
rate $\mathrm{t}$ years after exposure for sex $\mathrm{s}$ following

$\operatorname{EAR}(D, e, a)$ or $\operatorname{ERR}(D, e, a)=$ $\beta_{s} D \exp \left(\gamma e^{*}\right)\left(\frac{a}{60}\right)^{\eta}$. . . .1

Where $\mathrm{e}^{*}=\frac{e-30}{10}$ for $e<30$ and zero for $e \geq 30$, and $a=$ attained age (years).

$e=$ age at exposure, $\gamma=$ Per-decade increase in age at exposure over the range $0-30$ years.

$\eta=$ Exponent of attained age,$\quad \beta=$ ERR or EAR/ Sv for exposure (baseline cancer rate), $\mathrm{D}=$ effective dose in Sv.

Table 2 gives the values for the parameters $\beta, \gamma$ and $\eta$ which depends on the type of model (EAR or ERR model). For ERR model for most cancer sites, $\beta$ (the ERR per Sv) at age of exposure 30 and attained age 60 , tends to be larger for females than males. $\gamma=-0.3$ implies that the radiogenic risk of cancer at age "a" falls by about $25 \%$ for every decade increase in age at exposure up to 30 years and $\eta=-1.4$ implies that ERR is almost $20 \%$ smaller at attained age 70 years than at age 60. Thus ERR decreases with age at exposure (up to age 30) and attained age. In contrast, for EAR models, for most sites, $\gamma=-0.41$ and $\eta=2.8$. EAR decrease with age at exposure but increases with attained age (NAS, 2006).

Estimation of lifetime attributable risk (LAR) from the ERR and EAR models. For a person exposed to dose (x) at age (e), the LAR for different ages, sexes and cancer sites is given by (BEIR, 2006):

$$
\operatorname{LAR}(\mathrm{x}, \mathrm{e})=\int_{e+L}^{110} M(x, e, a) \cdot \frac{S(a)}{S(e)} d a
$$

exposure at age e to a dose $\mathrm{D}$ of radiation is given by

Where $M(x, e, a)=E A R(x, e, a)$ for EAR models and $\mathrm{M}(\mathrm{x}, \mathrm{e}, \mathrm{a})=\operatorname{ERR}(\mathrm{x}, \mathrm{e}, \mathrm{a}) \cdot \lambda_{1}(\mathrm{a})$ where $\lambda_{1}(\mathrm{a})$ is the baseline cancer incidence rate at age a. Where the boundary is from $a=e+L$ to 100, where $a$ denotes attained age (years) and $L$ is a risk-free latent period ( $L=5$ for solid cancers; $L=2$ for leukemia). The $M$ $(D, e, a)$ is the EAR, $S(a)$ is the probability of surviving until age $a$, and $S(a) / S(e)$ is the

probability of surviving to age $a$ conditional on survival to age $e$. All calculations are sex-specific; thus, the dependence of all quantities on sex is suppressed. The values of LAR are then obtained using equations 1 and 2 .

For simplicity, lifetime attributable risk (LAR) which is the sum from the exposure age plus latency to LAR upper limit of the yearly target population wEAR multiply by the probability of surviving to attained age, a given survival to exposure age e is given by $\operatorname{LAR}(\mathrm{x}, \mathrm{e})=\sum w_{E A R}$ target $\times \operatorname{survival}(\mathrm{a}) / \operatorname{survival}(\mathrm{e})$

$=\sum \mathrm{wEAR}_{\text {target }} \times \frac{\boldsymbol{s}(\boldsymbol{a})}{\boldsymbol{S}(\boldsymbol{e})} \quad 2 \mathrm{~b}$

Latency is 2 years for leukemia and 5 years for other cancers, LAR upper limit is 100 . Where

$\mathrm{wEAR}_{\text {target }}=\exp \left[\mathrm{w} \times \ln \left[\mathrm{EAR}_{\text {target }}\left(\mathrm{ERR}_{\text {atom-bomb }}\right)\right.\right.$ $+(1-\mathrm{w}) \times \ln \left[\mathrm{EAR}_{\text {target }}\left(\mathrm{EAR}_{\text {atom-bomb }}\right)\right]$

LAR is given in units of 100,000 patient $\times 0.1 \mathrm{~Sv}^{-1}$ and $\beta$ is in units of 10,000 patient year $\times \mathrm{Sv}^{-1}$ but mathematically the difference in number of patients cancels the difference in dose

Table 1: Total Committed Effective dose estimated due to ingestion of tap, well and river water

\begin{tabular}{|c|c|c|c|c|c|c|c|c|c|}
\hline \multirow{2}{*}{$\frac{6}{\text { SAMPLE TYPE }}$} & \multicolumn{3}{|c|}{ BABIES $(<1 \mathrm{a})$} & \multicolumn{3}{|c|}{ CHILDREN (1-13a) } & \multicolumn{3}{|c|}{ TEENS(13-17a) } \\
\hline & Tap $\mathrm{H}_{2} \mathrm{O}$ & Well $\mathrm{H}_{2} \mathrm{O}$ & River $\mathrm{H}_{2} \mathrm{O}$ & Tap $\mathrm{H}_{2} \mathrm{O}$ & Well $\mathrm{H}_{2} \mathrm{O}$ & River $\mathrm{H}_{2} \mathrm{O}$ & Tap $\mathrm{H}_{2} \mathrm{O}$ & Well $\mathrm{H}_{2} \mathrm{O}$ & River $\mathrm{H}_{2} \mathrm{O}$ \\
\hline OIL FIELDS & & & & & & & & & \\
\hline EBOCHA & 2.213849 & 9.870332 & 6.70391 & 0.794057 & 2.703499 & 1.803925 & 1.872056 & 7.441106 & 4.00466 \\
\hline MGBEDE & 6.043749 & 11.1634 & 7.07143 & 1.69116 & 3.017382 & 1.960896 & 4.921522 & 8.179978 & 5.227506 \\
\hline OBIAFU & 11.00421 & 20.49002 & 12.10961 & 3.107536 & 5.084796 & 3.032967 & 8.333948 & 14.12495 & 7.78784 \\
\hline OBRIKOM & 14.79731 & 23.65087 & 11.47651 & 3.856553 & 6.17202 & 3.406727 & 10.99154 & 17.79538 & 11.14259 \\
\hline EBEGORO & 2.02572 & 7.14395 & 6.33881 & 0.592388 & 2.153445 & 1.924119 & 1.255769 & 6.375536 & 5.774573 \\
\hline OMOKU & 5.686451 & 11.85115 & 13.36965 & 1.546359 & 26.34236 & 20.89926 & 3.576614 & 10.69497 & 9.206412 \\
\hline EREMA & 7.973518 & 12.91969 & 8.918285 & 10.62183 & 20.25192 & 14.1793 & 4.878321 & 8.909381 & 6.214078 \\
\hline IDU-OGBA & 2.789906 & 8.52434 & 6.86547 & 7.403284 & 16.64196 & 13.93502 & 2.929538 & 6.961804 & 5.784559 \\
\hline OBAGI & 6.93722 & 12.95452 & 10.37511 & 15.53919 & 25.13988 & 22.77142 & 6.307897 & 10.53219 & 9.287071 \\
\hline OGBOGENE & 7.497529 & 17.1352 & 15.86019 & 21.15952 & 34.04773 & 25.07329 & 10.6116 & 14.22123 & 10.47497 \\
\hline ODUGIRI & 10.21078 & 23.04043 & 20.51137 & 19.62194 & 48.87606 & 43.21961 & 8.232361 & 20.0653 & 17.76544 \\
\hline AGWE & 10.33425 & 18.06546 & 12.57721 & 21.64662 & 38.69331 & 26.32573 & 8.898989 & 15.82993 & 10.83674 \\
\hline Mean & 7.2929 & 14.6924 & 11.0148 & 8.96504 & 19.0937 & 14.8777 & 6.02586 & 11.76098 & 8.6256 \\
\hline
\end{tabular}

(Source: Avwiri and Ononugbo, 2012) 
Table 2: Parameter values for preferred risk models (BEIR, 2006)

\begin{tabular}{lllllllll}
\hline Cancer & ERR Model & \multicolumn{7}{c}{ EAR Model } \\
\hline & $\beta_{\mathrm{M}}$ & $\beta_{\mathrm{F}}$ & $\gamma$ & $\eta$ & $\beta_{\mathrm{M}}$ & $\beta_{\mathrm{F}}$ & $\gamma$ & $\eta$ \\
Stomach & 0.21 & 0.48 & -0.3 & -1.4 & 4.9 & 4.9 & -0.41 & 2.8 \\
Colon & 0.63 & 0.43 & -0.3 & -1.4 & 3.2 & 1.6 & -0.41 & 2.8 \\
Liver & 0.32 & 0.32 & -0.3 & -1.4 & 2.2 & 1 & -0.41 & 4.1 \\
Lung & 0.32 & 1.4 & -0.3 & -1.4 & 2.3 & 3.4 & -0.41 & 5.2 \\
Breast & & Not used & & & See text & & & -0.41 \\
Prostate & 0.12 & & -0.3 & -1.4 & 0.11 & & 2.8 \\
Uterus & & 0.055 & -0.3 & -1.4 & & 1.2 & -0.41 & 2.8 \\
Ovary & & 0.38 & -0.3 & -1.4 & & 0.7 & -0.41 & 2.8 \\
Bladder & 0.5 & 1.65 & -0.3 & -1.4 & 1.2 & 0.75 & -0.41 & 6 \\
Other solid & 0.27 & 0.45 & -0.3 & -2.8 & 6.2 & 4.8 & -0.41 & 2.8 \\
Thyroid & 0.53 & 1.05 & -0.83 & 0 & \multicolumn{7}{c}{ Not used } & & \\
\hline
\end{tabular}

\section{RESULTS AND DISCUSSION}

Table 3, 5 and 7 shows the ERR and EAR for male and female babies, children and teens respectively as a result of consumption of tap, well and river water in the host communities which was calculated using equation 1 and parameters in Table 2. The lifetime attributable risk (LAR) was calculated for male and female babies, children and teens respectively using equation 2 and presented in Table 4, 6 and 8 .

Table 3: Excess Relative Risk (ERR) and Excess absolute Risk (EAR) for Male and Female Babies

\begin{tabular}{|c|c|c|c|c|c|c|c|c|c|c|c|c|}
\hline \multicolumn{4}{|c|}{ male babies (err) } & \multicolumn{3}{|c|}{ female babies (err) } & \multicolumn{3}{|c|}{ male babies (ear) } & \multicolumn{3}{|c|}{ female babies (ear) } \\
\hline cancer site & tap & well & river & tap & well & river & tap & well & river & tap & well & river \\
\hline $\begin{array}{l}\text { Dose } \\
(\mathrm{mSv} / \mathrm{y})\end{array}$ & 7.29 & 14.7 & 11.0 & 7.29 & 14.7 & 11 & 7.29 & 14.7 & 11.0 & 7.29 & 14.7 & 11.0 \\
\hline Stomach & 9.7 & 19.5 & 14.6 & 22.1 & 44.6 & 33.3 & 16.9 & 34.2 & 25.5 & 16.9 & 34.1 & 25.5 \\
\hline Colon & 28.9 & 58.5 & 43.7 & 19.8 & 39.9 & 29.8 & 11.0 & 22.3 & 16.7 & 5.5 & 11.2 & 8.3 \\
\hline Liver & 15.0 & 30.4 & 22.7 & 14.7 & 29.7 & 22.2 & 3.1 & 6.2 & 4.7 & 1.4 & 2.8 & 2.1 \\
\hline Lung & 15.0 & 30.4 & 22.7 & 64.3 & 129.9 & 97.1 & 1.5 & 3.0 & 2.3 & 2.2 & 4.5 & 3.3 \\
\hline Breast & - & - & - & 14.9 & 30.1 & 22.5 & - & - & - & 28.0 & 56.6 & 42.3 \\
\hline Uterus & - & - & - & 2.5 & 5.1 & 3.8 & - & - & - & 4.1 & 8.3 & 6.2 \\
\hline Ovary & - & - & - & 17.5 & 35.3 & 26.4 & - & - & - & 2.4 & 4.9 & 3.6 \\
\hline Prostrate & 5.5 & 11.1 & 8.3 & - & - & - & 0.4 & 0.8 & 0.6 & - & - & - \\
\hline Bladder & 23.0 & 46.4 & 34.7 & 75.8 & 153.1 & 114.5 & 0.4 & 0.9 & 0.7 & 0.3 & 0.6 & 0.4 \\
\hline Thyroid & 42.9 & 86.7 & 64.8 & 85.0 & 171.7 & 128.4 & - & - & - & - & - & - \\
\hline Other & 32.7 & 66.1 & 49.4 & 54.6 & 110.2 & 82.4 & 21.4 & 43.2 & 32.3 & 16.6 & 33.4 & 25.0 \\
\hline
\end{tabular}

Table 4: Lifetime Attributable Risk (LAR) for Male and Female Babies

\begin{tabular}{lllllll}
\hline \multirow{2}{*}{$\begin{array}{l}\text { CANCER } \\
\text { SITE }\end{array}$} & $\begin{array}{c}\text { MALE BABIES (LAR) } \\
\text { TAP }\end{array}$ & WELL & RIVER & \multicolumn{2}{l}{ FEMALE BABIES (LAR) } \\
\hline Stomach & 175 & 354 & 264 & 233 & WELL & RIVER \\
Colon & & & & & 471 & 352 \\
Liver & 780 & 1577 & 1179 & 525 & 1061 & 793 \\
Lung & 131 & 265 & 198 & 63 & 128 & 96 \\
Breast & 700 & 1414 & 1057 & 1670 & 3374 & 2522 \\
Uterus & - & - & - & 1626 & 3286 & 2456 \\
Ovary & - & - & - & 102 & 206 & 319 \\
Prostrates & - & - & - & 211 & 427 & - \\
Bladder & 233 & 471 & 352 & - & 1046 & 782 \\
Thyroid & 503 & 1017 & 760 & 518 & 1105 & 826 \\
Other & 102 & 206 & 154 & 547 & 3138 & 2346 \\
\hline
\end{tabular}


Table 5: Excess Relative Risk (ERR) and Excess Absolute Risk (EAR) for Male and Female Children

\begin{tabular}{|c|c|c|c|c|c|c|c|c|c|c|c|c|}
\hline \multicolumn{4}{|c|}{ male children (err) } & \multicolumn{3}{|c|}{ female children (err) } & \multicolumn{3}{|c|}{ male children (ear) } & \multicolumn{3}{|c|}{ female children (ear) } \\
\hline cancer site & tap & well & river & tap & well & river & tap & well & river & tap & well & river \\
\hline $\begin{array}{l}\text { Dose } \\
\left(\mathrm{mSvy}^{-1}\right)\end{array}$ & 8.97 & 19.1 & 14.9 & 8.97 & 19.1 & 14.9 & 8.97 & 19.1 & 14.9 & 8.97 & 19.1 & 14.9 \\
\hline Stomach & 13.7 & 17.6 & 13.7 & 31.4 & 40.3 & 31.4 & 12.7 & 27.1 & 21.1 & 12.7 & 27.1 & 21.1 \\
\hline Colon & 41.2 & 52.9 & 41.2 & 28.1 & 36.1 & 28.1 & 8.3 & 17.7 & 13.8 & 4.2 & 8.8 & 6.9 \\
\hline Liver & 20.9 & 26.8 & 20.9 & 20.9 & 26.8 & 20.9 & 2.3 & 4.9 & 3.8 & 1.0 & 2.2 & 1.7 \\
\hline Lung & 20.9 & 26.8 & 20.9 & 91.5 & 117.5 & 91.5 & 1.1 & 2.4 & 1.9 & 1.7 & 3.6 & 2.8 \\
\hline Breast & - & - & - & 30.4 & 39.0 & 30.4 & - & - & - & 18.6 & 39.7 & 30.9 \\
\hline Uterus & - & - & - & 3.6 & 4.6 & 3.6 & - & - & - & 3.1 & 6.6 & 5.2 \\
\hline Ovary & - & - & - & 24.8 & 31.9 & 24.8 & - & - & - & 1.8 & 3.9 & 3.0 \\
\hline Prostrates & 7.8 & 10.1 & 7.8 & - & - & - & 0.3 & 0.6 & 0.5 & - & - & - \\
\hline Bladder & 32.7 & 41.9 & 32.7 & 107.9 & 138.4 & 107.9 & 0.3 & 0.7 & 0.6 & 0.2 & 0.4 & 0.3 \\
\hline Thyroid & 32.3 & 41.5 & 32.3 & 64.0 & 82.2 & 64.0 & & & & & & \\
\hline Other & 46.6 & 59.8 & 46.6 & 77.6 & 99.6 & 77.6 & 16.1 & 34.3 & 26.7 & 12.5 & 26.5 & 20.7 \\
\hline
\end{tabular}

Table 6: Lifetime Attributable Risk (LAR) for Male and Female Children

\begin{tabular}{lllllll}
\hline \multicolumn{3}{c}{ MALE CHILDREN (LAR) } & \multicolumn{4}{c}{ FEMALE CHIDREN (LAR) } \\
$\begin{array}{l}\text { CANCER } \\
\text { SITE }\end{array}$ & TAP & WELL & RIVER & TAP & WELL & RIVER \\
\hline Stomach & 215 & 458 & 357 & 287 & 611 & 476 \\
Colon & 959 & 2043 & 1592 & 645 & 1375 & 1071 \\
Liver & 161 & 344 & 268 & 78 & 166 & 129 \\
Lung & 861 & 1833 & 1428 & 2053 & 4372 & 3407 \\
Breast & - & - & - & 1999 & 4258 & 3318 \\
Uterus & - & - & - & 126 & 267 & 208 \\
Ovary & - & - & - & 260 & 554 & 431 \\
Prostrates & 287 & 611 & 476 & - & - & - \\
Bladder & 619 & 1317 & 1027 & 637 & 1356 & 1056 \\
Thyroid & 126 & 267 & 208 & 672 & 1432 & 1116 \\
Other & 1739 & 3704 & 2886 & 1910 & 4067 & 3169 \\
\hline
\end{tabular}

Table 7: Excess Relative Risk (ERR) and Excess Absolute Risk (EAR) for Male and Female Teens

\begin{tabular}{|c|c|c|c|c|c|c|c|c|c|c|c|c|}
\hline \multicolumn{4}{|c|}{ male teens (err) } & \multicolumn{3}{|c|}{ female teens (err) } & \multicolumn{3}{|c|}{ male teens (ear) } & \multicolumn{3}{|c|}{ female teens (ear) } \\
\hline cancer site & tap & well & river & tap & well & river & $\operatorname{tap}$ & well & river & $\operatorname{tap}$ & well & river \\
\hline $\begin{array}{l}\text { Dose } \\
\left(\mathrm{mSvy}^{-1}\right)\end{array}$ & 6.07 & 11.8 & 8.63 & 6.07 & 11.8 & 8.63 & 6.07 & 11.8 & 8.63 & 6.07 & 11.8 & 8.63 \\
\hline Stomach & 5.0 & 9.6 & 7.1 & 11.4 & 22.0 & 16.1 & 7.3 & 14.1 & 10.4 & 7.3 & 14.1 & 10.4 \\
\hline Colon & 14.9 & 28.9 & 21.2 & 10.2 & 19.7 & 14.5 & 4.8 & 9.2 & 6.8 & 2.4 & 4.6 & 3.4 \\
\hline Liver & 7.6 & 14.7 & 10.8 & 7.6 & 14.7 & 10.8 & 1.3 & 2.6 & 1.9 & 0.6 & 1.2 & 0.9 \\
\hline Lung & 7.6 & 14.7 & 10.8 & 33.1 & 64.2 & 47.1 & 0.6 & 1.3 & 0.9 & 1.0 & 1.9 & 1.4 \\
\hline Breast & - & - & - & 12.4 & 24.0 & 17.6 & - & - & - & 10.3 & 20.0 & 14.6 \\
\hline Uterus & - & - & - & 1.3 & 2.5 & 1.9 & - & - & - & 1.8 & 3.5 & 2.5 \\
\hline Ovary & - & - & - & 9.0 & 17.4 & 12.8 & - & - & - & 1.0 & 2.0 & 1.5 \\
\hline Prostrates & 2.8 & 5.5 & 4.0 & - & - & - & 0.2 & 0.3 & 0.2 & - & - & - \\
\hline Bladder & 11.8 & 22.9 & 16.8 & 39.0 & 75.7 & 55.5 & 0.2 & 0.4 & 0.3 & 0.1 & 0.2 & 0.2 \\
\hline Thyroid & 9.5 & 18.3 & 13.4 & 18.7 & 36.3 & 26.6 & & & & & & \\
\hline Other & 16.9 & 32.7 & 24.0 & 28.1 & 54.4 & 39.9 & 9.2 & 17.9 & 13.1 & 9.2 & 17.9 & 13.1 \\
\hline
\end{tabular}

Table 8: Lifetime Attributable Risk (LAR) for Male and Female Teens

\begin{tabular}{|c|c|c|c|c|c|c|}
\hline \multirow[b]{2}{*}{ CANCER SITE } & \multirow[b]{2}{*}{ TAP } & \multicolumn{2}{|c|}{ MALE TEENS (LAR) } & \multicolumn{3}{|c|}{ FEMALE TEENS (LAR) } \\
\hline & & WELL & RIVER & TAP & WELL & RIVER \\
\hline Stomach & 146 & 282 & 207 & 194 & 376 & 276 \\
\hline Colon & 649 & 1258 & 923 & 437 & 847 & 621 \\
\hline Liver & 109 & 212 & 155 & 53 & 102 & 75 \\
\hline Lung & 582 & 1129 & 828 & 1389 & 2693 & 1975 \\
\hline Breast & - & - & - & 1353 & 2623 & 1923 \\
\hline Uterus & - & - & - & 85 & 165 & 121 \\
\hline Ovary & - & - & - & 176 & 341 & 250 \\
\hline Prostrates & 194 & 376 & 276 & - & - & - \\
\hline Bladder & 419 & 812 & 595 & 431 & 835 & 612 \\
\hline Thyroid & 85 & 165 & 121 & 455 & 882 & 647 \\
\hline Other & 1177 & 2282 & 1673 & 1292 & 2505 & 1837 \\
\hline
\end{tabular}


In Table 3, the excess relative risk (ERR) and excess absolute risk (EAR) calculated for male babies due to ingestion of tap, well and river water varied from 5.5 to $42.9,11.1$ to 86.7 and 8.3 to 64.8 respectively while the female babies recorded ERR ranging from 2.5 to 85.0, 5.1 to 71.7 and 3.8 to 128.2 respectively. It was observed that cancer risk which is the excess probability of developing cancer was least in male babies prostrate and female babies breast while the thyroid gland recorded the highest risk in both male and female babies. Also the excess absolute risk (EAR) to male and female babies due to ingestion of tap, well and river water recorded the lowest risk to prostrate for male and bladder in female babies. The highest risk was recorded in the male baby's stomach and female baby's breast.

Table 5 presents the excess relative risk and excess absolute risk to children due to ingestion of tap, well and river water from the studied area. The lowest excess relative risk (ERR) calculated for male children was recorded on the prostrate while the highest risk was recorded on the colon. Their female counterpart had the lowest risk on the uterus and highest on the bladder. The excess absolute risk (EAR) estimated for male and female children due to ingestion of tap, well and river water also recorded that prostrate and bladder had the least risk in male and female children respectively while the highest risk was recorded on the stomach and breast respectively. The result is the same for the teenagers as recorded in Table 7. This result shows that the thyroid gland, stomach and breast of humans are very sensitive to radiation and should be properly shielded in case of x-rays in medical diagnosis.

Table 4 presents lifetime attributable risk for the same dose of $7.29 \mathrm{mSv} / \mathrm{y}$ calculated from intake of tap water, it is estimated that 102 male babies per 100,000 will likely have cancer of the thyroid during their lifetime. This is much lower when compared with the value of LAR for female babies. From Table 2, 547 female babies per 100,000 will likely have cancer of the thyroid during their lifetime. This means that about $84 \%$ of babies are likely to have cancer in their lifetime are females while their male counterparts account for $16 \%$. The values calculated for this study area is far higher than that calculated in Hong Kong by Feng et al., (2010). Feng et al., (2010) estimated a LAR for thyroid cancer of 4 per 100,000 in 5-year-old boys and 21 per 100,000 for girls. The cancer registries in Ibadan and Abuja reported by Elima Jedy-Agba et. al. (2012), shows 2985 (66\%) cancer incidents in females and 1536 (34\%) cancer incidents in males. This agrees with this paper that females are more at risk when compared with their male counterparts

The result shows that LAR tends to reduce as age-atexposure increases. The LAR for children in this work is higher than that of babies as seen in LAR for stomach cancer. The LAR for stomach cancer for female babies is 233 per 100,000 as result of tap water consumption while that of female children is 287 per 100,000 . This increase in LAR for children against babies could be due to a higher consumption of water in children than babies. According to
Ismail et al., (2008), babies consume 0.5 litre of water daily while children consume 1 litres of water daily. This could be a factor that is responsible for the elevated value of ERR/Sv (Table 3, 5 and 7) and LAR for all cancer sites for children when compared with babies.

It was also observed that the cancer risk due to consumption well and river water is much higher than the risk due to consumption of tap water. From Table 6, the LAR for male children due to consumption of tap, well and river water are 161,344 and 268 per 100,000 respectively for liver cancer. This shows that well water presents the highest risk, next to river water and then tap water. This was observed for all sites, sexes and ages. The LAR values calculated in the results show that the level of risk of cancer for different sites is age-at-exposure dependent. It also shows that females are more at risk when compared with their male counterparts.

The LAR calculated for teens due to ingestion of tap water in the study area is not as high as that recorded for babies and children but is still higher than that recorded by Levi, (2010) and Hany et al.,(2012). The mean LAR for female teens is 587 per 100,000 while that of male is 420 per 100,000 . This is far higher than what was reported by Levi, (2010). Levi, (2010) reported a LAR for all cancer sites for the young adults in the University of Ilorin as 41 (per 100,000) for males and 57 (per 100,000) for females. This profound difference could be as a result of high activity concentration of radionuclides recorded in all water sources studied which may be due to oil and gas exploitation activities in the study area that has made possible the filtration of radionuclides into the aquifer.

Conclusion: The estimation of radiation risks due to radiation exposure from water using radiation risk models has been carried out on the population in the oil rich area of Ogba/Egbema/Ndoni oil and gas fields. The result showed a linear dose-response relationship, the higher the doses, the higher the risk. The study showed an increase in lifetime attributable risk (LAR) as age at exposure reduces. It also shows that females have generally higher risk compared to their male counterparts and there are higher risks for those who consume well and river water in comparison with those who consume tap water. Based on the estimated risks in this study, regular and periodic monitoring of radiation levels of oil and gas installations and their host communities should be adopted and Safe drinking water should be provided for the host communities by the oil companies operating in the area.

\section{REFERENCES}

Ajibode, M.O., Avwiri G.O and Agbalagba, E.O (2012). Evaluation of Radiation Hazard Indices in Oil Mineral Lease (Oil Block) in Delta State, Nigeria. International Journal of Engineering and Applied Sciences. 4(2): 35-45, ISSN2305-8269.

Alberg AJ, Brock MV, Samet JM (2005). Epidemiology of lung cancer: Looking to the future. J. Clinical Oncology., 23: 3175-3185. 
Alberg AJ, Samet JM (2003.) Epidemiology of lung cancer. Chest, 123: 21S-49S. Committee to Assess Health Risks from Exposure to Low Levels of Ionizing Radiation; Board on Radiation Effects Research (BIER); Division on Earth and Life Studies (DELS); National Research Council. Health Risks from Exposure to Low Levels of Ionizing Radiation: BEIR VII-Phase 2; National Academies Press: Washington, DC, USA, 2006.

Avwiri G.O. and Ononugbo, C.P. (2012). Assessment of NORM Content of Hydrocarbon Exploration and Production Activities of Ogba /Egbema/Ndoni Oil/Gas Fields, Nigeria. Indian Journal of Innovations and Development. 1(1):9-14

Elima Jedy-Agba, Maria P. C., Olufemi O., Emmanuel O., Toyin F., Festus I., Gloria O., Theresa O., Henry K., Alice K., Patience O., Patrick D., William B., Clement A. A. (2012). Cancer incidence in Nigeria: A report from population-based cancer registries. http://dx.doi.org/10.1016/i.canep.2012.04.007

Feng, S.-T.; Law, M.-W.; Huang, B.; Ng, S.; Li, Z.-P.; Meng, Q.-F.; Khong, P.-L. (2010). Radiation dose and cancer risk from pediatric $\mathrm{CT}$ examinations on 64slice CT: A phantom study. European Journal of Radiology. 76:19-23.

Ferlay J, Shin HR, Bray F, Forman D, Mathers C, Parkin DM. (2010). Estimates of worldwide burden of cancer in 2008: GLOBOCAN 2008. International Journal of Cancer 127:2893-917.

Godson R. E., Mynepalli K. C. and Michael C. (2010). Environmental risk factors and hospital-based cancers in two Nigerian cities. Journal of Public Health and Epidemiology 2(8): 216-223, November 2010 ISSN 2141-2316
Hany, E., Marwa, A.H., Abdel Mageed, A.I, El-Attar, A.L. (2012). XI Radiation Physics and Protection Conference, Nasr city-Cairo, Egypt, pp 25-28.

Hany El-Gamal and Abdallah I.A. EL- Mageed (2014). Natural Radioactivity in water samples from Assiut city, Egypt. International journal of pure and Applied Science and Technology. 22(1):44-52.

Ismail, A.M., Kullab, M.K and Saq'am, S.A. (2009). Natural Radionuclide in bottled drinking water in Jordan and their committed effective doses: Jordan Journal of Physics 2(1):47-57.

Levi I. Nwankwo (2010). Annual Effective Dose Due to Combined Concentration of ${ }^{226} \mathrm{Ra}$ and ${ }^{228} \mathrm{Ra}$ in the Ground water system: A Case Study of the University of Ilorin main campus, Nigeria: Working and Living Environmental Protection. 7(1): 53-58.

Nour Khalifa Ahmed (2004). Natural Radioactivity of ground and drinking water in some areas of Upper Egypt. Turkish Journal of Environmental Engineering Sciences. 28: 345-354

Sylla BS, Wild C.P (2011). A million Africans a year dying from cancer by 2030: what can cancer research and control offer to the continent? International Journal of Cancer

Wardwell NR, Massion PP (2005). Novel strategies for the early detection and prevention of lung cancer.Seminar Oncology. 32: 259-268.

William, R., Handee, E., Michael, K., and Connor, O. (2012). Radiation Risks of Medical Imaging; Separating Fact from Fantacy. Radiology: 264 (2):311-318

Yin-Ping, S., Hao-Wei, N., Jun-Bo, C., Ying-Hua, F., GuoBing, X. and Quan-Fu, S. (2014). International Journal of Environmental Research and Public Health ISSN 1660-4601 www.mdpi.com/journal/ijerph 